\title{
HOW COVID-19 HAS AFFECTED OPERATIONS \& FUNDING RELATING TO SOCIAL ENTERPRISES IN BIRMINGHAM
}

\author{
S M Nazmuz Sakib \\ Graduate of BSc in Business Studies \\ School of Business And Trade \\ Pilatusstrasse 6003, 6003 Luzern, Switzerland \\ sakibpedia@gmail.com \\ Student of Department of Law \\ Dhaka International University \\ House \# 4, Road \# 1, Block - F, Dhaka 1213 \\ sakibpedia@students.diu.ac
}

\section{ABSTRACT}

Social enterprises are very common in Birmingham having the largest concentrations of social enterprises in the United Kingdom. With the emergence of the Covid-19 pandemic, the operations and management of social enterprises in Birmingham has been greatly affected. This study seeks to analyse the impact of the Covid-19 pandemic on the operations and funding of social enterprises in Birmingham UK. In order to achieve this, the study is going to carry out a qualitative methodology in order to analyse the impact Covid-19 has had on social enterprises. The research is going to select relevant stakeholders through a non-purposive sampling criteria identifying individuals who have direct interest in the functioning of social enterprises. The relevant stakeholders will be expected to respond to semi structured interviews that are structured to evoke responses relevant to this area of research. The research realized that Social enterprises in Birmingham are a critical player in the economy of UK with many individuals depending on the social enterprise industry. In addition to that, the study realised that the Covid-19 pandemic exposed social enterprises to various financial and market risks. Moreover, social enterprises were forced to make a change in their organizational structure through cost management changes and offering alternative services. However, the government came in support through provision of grants and funding to boost the social enterprise economy. 


\section{Keywords}

Corona, Covid-19,

Pandemic,

Business,

Affected business,

Social,

Operations,

Funding 


\section{INTRODUCTION}

\subsection{Background of the Study}

Considering the high transmission rates of Covid-19 infection, the World Health Organization declared it a global pandemic (Biswas et al., 2020a). To preventing covid19 from spreading internationally, it is imperative to put strict measures to stop the virus's spreading. The measures involved the limitation of human interaction and the closure of various institutions and organisations. As a result, the inforced measures have impacted various businesses and normal operations (Kowalski et al., 2020).

Since the onset of the Covid-19 pandemic in 2019, there have been significant transformations in society's health, social and economic spheres (Leach, MacGregor, Scoones, \& Wilkinson, 2021). Given the highly infectious nature of the infection, there arose the need for various restrictions to control the infection's spread. (Pan \& Zhang, 2020). The Covid-19 pandemic made many governments across the world declare the closure of the non-essential sectors of the economy as one way of mitigating the spread of the infection (Gatto et al., 2020).

The non-essential sector has contributed to the economic fallout, which has been experienced in all parts of the world (Reeves, McKee, \& Stuckler, 2014). It has been reported that the economic downturn has majorly affected low-income and casual workers (Adams-Prassl, Boneva, Golin, \& Rauh, 2020). Most non-essential employees have either been furloughed or laid off, leading them into bankruptcy. A recent study highlighted that the likely ratio of bankruptcies due to the Covid19 outbreak would be more than the deaths caused by the covid virus (Hsiang et al., 2020). In addition to that, the mitigation measures of the Covid-19 pandemic contributed to a significant reduction of income, unemployment, poverty, among many more (Bittihn, Hupe, Isensee, \& Golestanian, 2021). The extreme consequences can be attributed to many governments underestimating the risk related to the spread of the Covid-19 pandemic (Chowell \& Mizumoto, 2020).

Birmingham is the UK's second city with a population of more than 1 Million. Birmingham's high population played a critical role in the spread of Covid-19 cases (Ghosh, Nundy, Ghosh, \& Mallick, 2020). Although it was not the country's worst-hit area, it was adversely affected by the devastating effects of the Covid-19 pandemic (Ghosh et al., 2020). 
One of the critical sectors of society that were adversely affected by the Covid-19 pandemic is social enterprises. Social enterprises are businesses that make profits while achieving societal goals (Lambooy, Anthoni, \& Argyrou, 2020). More often than not, making profits is not the fundamental goal of social enterprises (Lambooy et al., 2020). The profits obtained from their operations are often used to fund and sustain social programs (Lambooy et al., 2020). Social enterprises obtain their funding from grants and donations (Lambooy et al., 2020).

The Greater Birmingham and Solihull Local Enterprise Partnership (GBSLEP), an enterprise partnership set up by the England government to drive economic development, recognised social entrepreneurship's role in driving economic prosperity in England (BSSEC, 2014). The social enterprise sector in Birmingham, UK, has grown significantly in the recent past. It is reported that there were approximately 450 to 500 social enterprises in greater Birmingham in the year 2014, generating a combined gross revenue of 180 Million Euros (BSSEC, 2014). Social entrepreneurship has also become an excellent employment source in Birmingham, providing employment opportunities for over 14,600 individuals (BSSEC, 2014). Social entrepreneurship in Birmingham generates its income mainly through trade. The BSSEC report states that $86 \%$ of the income generated by social enterprises in Birmingham is obtained from trading, and the remaining $14 \%$ is generated from grants, donations, and other sources (BSSEC, 2014).

As a result of the Covid-19 pandemic, operations and funding of social enterprises in Birmingham and the entire UK have been negatively affected (Obrenovic et al., 2020). A recent survey of 550 charities by the Institute of Fundraising stated that $48 \%$ of social enterprises in the UK risk losing their voluntary income due to the Covid-19 pandemic (Hatch, 2020). It is reported that there was a $41 \%$ increase in direct debit cancellations for social enterprises in April 2020 in the UK (Melanie Rapidata, 2020). Moreover, the emergence of the Covid-19 pandemic made social enterprises cut back their operations due to the income drop. Reports have indicated that $60 \%$ of social enterprises in the UK cut back on their staff by April 2020 (Hatch, 2020). Social enterprises took measures that involved postponing programs' implementation, closing their office set up, limiting their activities, among many more (Hatch, 2020). 
In Birmingham, the emergence of the Covid-19 pandemic had a profound effect on social enterprises (Social Enterprise UK, 2020). As a result of the pandemic, social enterprises have faced significant operational and financial consequences alongside a spike in demand for services, a reduction in an employment capacity, and a reduction in funding capacity (Social Enterprise UK, 2020).

The covid-19 pandemic created a problem that was not anticipated (Yoosefi Lebni et al., 2020). The pandemic came unexpectedly, with the social entrepreneurs uninformed on any possible means to handle the impact (Yoosefi Lebni et al., 2020). With the unforeseen problem, implementing contingencies for survival may be challenging for this sector, like many other sectors facing the same threat (Yoosefi Lebni et al., 2020). Concomitantly, most enterprises have not adopted feasible technologies and could cushion the organisations in uncertainty (Hope \& Player, 2012).

Since the pandemic's impact on various entities is still unexplored, it is vital to research the effects caused by the pandemic on the sector. The study is significant in defining strategies to be implemented in such outbreaks and unforeseen circumstances (Holmes, 2008). Therefore, this study evaluates the impacts of the Covid-19 pandemic on the social enterprises and analyses challenges encountered—whilst providing solutions for the future of operations.

The research evaluates the impact Covid-19 has had on the social enterprises and their operations within Birmingham city in the UK; Providing insight into the industry's performance during the pandemic and survival after the pandemic. Moreover, the research will cover different businessrelated theories to understand these factors' impact on the business. The research outcome will be beneficial to the investors and entrepreneurs in determining the approaches to survive the industry. It will also be beneficial as a reference point for the investors who wish to start their operations in the UK.

\subsection{Statement of the Problem}

Different sectors of the UK economy have experienced economic disruption due to the Covid-19 pandemic (Mark Stephens, 2020). Besides, the Covid-19 pandemic had an abrupt impact on operations in almost all industries globally (Yoosefi Lebni et al., 2020). Countless businesses have 
been impeded following the closures, limitation of operations, limitation of movements, reduction in consumption, among many more. According to Bartik (2020), even though some businesses gained from the pandemic, most were negatively affected, particularly those considered nonessential. Social enterprises serve a critical role in society in providing solutions to the challenges in a broad scope of cultural and environmental issues (Katz \& Page, 2010). However, COVID 19 has impacted social enterprises because of the increased cost of conducting business, reducing consumer demand, and reducing grants by funding organisations. (Petrakis, 2020). The pandemic effects present a significant need to monitor the enterprises' performance concerning their social and organisational goals. This research study will evaluate and analyse and address the pandemic's impact on social enterprises.

\subsection{Justification of the Study}

Social enterprises play an essential role in achieving global social development goals (Skilled Impact, 2018). There is a vital necessity to understand how social enterprise businesses operate and deliver services alongside the strict contingent regulations resulting from the Covid-19 pandemic. This study is crucial as it will identify the appropriate contingency strategies for the smooth and progressive functioning of the social enterprises amid the pandemic. There is a lack of sufficient information on the impact of Covid-19 on social enterprises' funding and operation. It is essential to analyse the negative impact of Coronavirus on social enterprises to bridge the research gap on the effects of the pandemic within Birmingham.

\subsection{Objectives of the Study}

\subsubsection{General Objective}

To evaluate the impact of Covid-19 on the operations and funding of social enterprises.

\subsubsection{Specific Objectives}

I. To identify how customer expectations and needs are influencing business practices and service delivery in the Covid-19 era.

II. To evaluate the effects of Covid-19 on the operations and funding of social enterprises in Birmingham, UK.

III. To predict and effect that the Covid-19 pandemic will have on future operations on social enterprises.

IV. To determine the various ways social enterprises can reconfigure to minimise pandemic and future uncertainties through an effective contingency plan. 


\subsection{Research Questions}

I. How are the social enterprises suited to the uncertainties in their operations?

II. How has the Covid-19 pandemic affected operations within social enterprise businesses in Birmingham?

III. How has the pandemic contributed to the challenges in the funding of social enterprises in Birmingham?

IV. What are the key factors that need to be considered in social enterprises that keep them shield against uncertainties in the future of their operations?

\subsection{Limitations of the Study}

The impact of the Covid-19 pandemic has been experienced in almost all regions across the world. Social enterprises worldwide have felt the impact of the pandemic (Lenzen et al., 2020). There is limited research on the impact of the covid-19 pandemic on the social enterprise in Birmingham. Social enterprises also consist of different functions in their entirety; The focus is on the general operations of the second entities' funding concerning how they have been affected. 


\section{Literature review}

\subsection{Introduction}

The chapter provides a literature review of the social enterprise's operation and how such pandemics have affected various businesses' operations. The section entails a comprehensive look at the studies that have been written about the pandemic affecting social enterprise's operations and funding; The review will highlight the pandemic's impact. This section also carries out a critical review of the contingency plans that the social enterprises need to take to ease the consequences of the Covid-19 pandemic.

\subsection{Research gap}

The COVID-19 pandemic is an uncommon virus that emerged. The first known infections were first reported in Wuhan, China, which spread throughout the world, becoming a global pandemic (Kumar, Malviya, \& Sharma, 2020). Although there have been other pandemics in history, the scale of Covid-19 has been extraordinary as it has affected the entire world. Other pandemics, such as the Spanish Influenza-1918, occurred before and caused considerable damage to the economy (Crosby, 2003). There is an assortment of research studies carried out on the impact of pandemics on the economy.

Studies carried out have focused on various businesses with little to no research covering the Coronavirus's impact on social enterprises' operation (Biswas et al., 2020b). The pandemic has caused a significant impact, and it presents a need to analyse the different entities that have been affected. The findings will provide data on the effects of various recommendations for various organisations to deal with unknown circumstances.

The pandemic provides an avenue to explore and study to add to the field of knowledge. The consequences of enterprises have not been explored, especially enterprises in Birmingham, UK. The research will be significant to assist within the research gap. It is also evident that social enterprises have not encountered a downtime period in the face of such a pandemic (Aruru, Truong, $\&$ Clark, 2021). The study will help identify the pandemic's significant consequences on social enterprises through a Birmingham city case study. 


\subsection{Social enterprises}

Social enterprises are defined as entities that use commercial strategies to maximise financial, environmental, and social well-being (Katz \& Page, 2010). The majority are presented to be structured both for-profits or nonprofit and, in most cases, developed as cooperatives, mutual organisations, social business, community interest companies as well as charitable organisations (T. London \& Hart, 2010). At the foundational level, social enterprises are constituted to help the disadvantaged in society by implementing a market solution. Under the EU's Social Business initiative, the social enterprises factor in the dimensions of entrepreneurship, social, and governance (Kerlin, 2006). According to Kerlin (2006), the entrepreneurship aspect indicates the element of engaging in continuous business. The social dimension depicts the primary goal of social enterprises that are defined in the societal benefit. In comparison, the governance dimension shows that a social enterprise needs to be based on a mechanism and structure to ensure that the organisational goals are maintained and attained. The Social Business Initiative (SBI) under the EU defined the above dimensions' operational criteria to ensure they are reflected in the social enterprises (Kerlin, 2006).

\subsection{Social enterprises in the UK}

The concept of social enterprises first came up in the 1970s in the UK (Defourny \& Nyssens, 2008). These were developed as an alternative to the commercial, organisational, public enterprises, cooperatives, and private entities. In social enterprises, they applied two paradigm shifts: a typical ownership legal structure and a democratic form of governance. As part of the principles, the enterprises comprised the core values: trading and financially viable independence,creating social wealth, and operating in environmentally responsible ways (Bull \& Ridley-Duff, 2008).

Kerlin (2006) indicates that the social entrepreneurship concept has gained ground in most regions globally over the last two decades. Thus, such regions, especially in Europe and the United States, increasingly gain significant social enterprise grounds (Kerlin, 2006). In Europe, the formation of the EMES European Research came as a significant boost to the spread of the information regarding the concept, which saw its increased growth through the period (Defourny \& Nyssens, 2014). The EMES network initially had four economic criteria for guiding social enterprise's formation. In this, the EMES defined the enterprises as "nonprofit private organisations providing goods/services directly related to their objectives and aims to benefit the community (Defourny \& 
Nyssens, 2014). They are founded on an array of dynamics with various stakeholders in their governing bodies, hold a high value on their autonomy bearing various economic risks according to the activity they are involved in (Defourny \& Nyssens, 2008)"

Some social enterprises can be under private for-profit and the public sector (Defourny, 2013). However, different parts of Europe have adopted different approaches. Therefore, they can be located within the third sector or in the social economy, which is usually oriented towards nonprofit organisations and cooperatives and not-for-profit private enterprises (Defourny \& Nyssens, 2006).

Italy is the pioneering region of social enterprises (Adam, 2004). New initiatives in the country to heed to the demand for unmet needs in the 1980s led to the emergence of the cooperate initiatives (Tidd \& Bessant, 2020). Under the sector of work integration, groups had suffered under increased exclusion from the labour market. The process was coupled with excluding personal services under the increased ageing population and dynamic family structures (Tidd \& Bessant, 2020). The new cooperatives' significance was that they were serving the broader community, emphasising the dimension of general interest instead of the old ones, which was focused on the members' interests (M. London \& Morfopoulos, 2009). Under the pioneering of these new cooperatives, the stakeholders were made from different backgrounds and classes, seeking to embody a wellrepresented entity (Nicholls, 2013). The Italian laws were then reinforced to support the composition and the enterprises' continued distinction from similar entities such as social institutions offering social services (M. London \& Morfopoulos, 2009).

In his research, Doherty (2006) indicated that the UK had not been long in adopting this concept. Once Italy had defined the social enterprise's role within the various legal frameworks, the UK advanced a social enterprise definition (Doherty et al., 2006). The definition advanced that social enterprises are the social objectives as the primary goal whose surpluses are principally reinvested in the community rather than driven by the need to maximise profits for the stakeholders and the owners. Both in the UK and Italy, social enterprises are grouped under the third sector (Defourny, 2013). The estimation in the UK in 2005 indicated that there was an average of 15000 social enterprises (Lyon \& Sepulveda, 2009). The figures are given as an estimate under the contention that there was no clear distinction of the sector from other organisations. An updated estimate indicates approximate 68000 social enterprises in the UK with a turnover of 24 Euros to the economy (Lyon \& Owen, 2019). 
The first agency in the UK was formed in 1998 to merge two bodies that supported cooperative enterprise and was referred to as Social Enterprise London (Defourny \& Nyssens, 2008). Apart from supporting emerging businesses, the agency collaborated with the London Development agency to create a community of interest. To gather individual perceptions on the phenomena, built a great network of over 2000 social enterprises and social entrepreneurship. Through this, over 500 jobs were made available for persons living with disabilities (Adam, 2004).

The Social enterprise unit was created in 2002 by the British government, under the unified strategy to coordinate implementation and support for social development's (Bailey, Kleinhans, \& Lindbergh, 2018). The policy formulation was later informed and influenced by the organisations in the nonprofit sector. The social enterprise unit initially established within the trade and industry department was later in 2006 and moved into the third sector under the Cabinet Office wing (Young, 2013).

Social enterprises involve community enterprises, charities, employee-owned businesses, credit unions, development trusts, social firms, housing associations and leisure trusts (Dorigo, 2010). Under the UK definition, the profits in this sector are often driven by social aims which the business has identified (Dorigo, 2010). The aims may include but are not limited to providing education to the needy and disabled, addressing environmental issues or community development. Later, through the social enterprise unit, the definition was broadened to include companies limited to shares, unincorporated associations, partnerships and sole traders in addition to the companies limited by guarantee and industrial and provident societies (Defourny \& Nyssens, 2008).

\subsection{The operation and role of social enterprises today}

Since their inception, social enterprises have gained popularity even globally. The popularity may be attributed to increased knowledge amongst the population and increased consciousness to provide solutions to societal issues (Adam, 2004). According to Adam (2004), the twenty-first century has continually encountered problems that have necessitated various entities' intervention to solve. The need has been an aggravating factor in forming and implementing social enterprises to formulate strategies and policies from individual and organisational perspectives (Lyon \& Owen, 2019). 
The rise of social enterprises has necessitated legislation and regulations of operation across different regions. However, it has been indicated that Germany and Japan have not passed any federal law on social enterprises' definition, but they still have them in their countries (Stinchcombe, 2000). The different approaches speak to the different levels of adoption and operations in each country. Certain countries have had the sector in operation for a much greater period than others. Therefore their legislative and policy frameworks are much established, making their initiatives more advanced and better coordinated (Kerlin, 2009).

The operation of the sector under the element of work integration is defined under the following:

Integration objectives- this concept relates to training and employment aspects, the type of job contracts and the target groups. It involves training for social integration and works professionalism.

Training and job contracts- the element is mainly oriented towards providing job training in different fields. Other entities are geared toward providing formal and informal training and learning.

The target groups- the social enterprises concern themselves to a particular target in the market or can be defined on a general objective of serving society. Under the general service, the social enterprise's scope is defined by the type of objective it delivers. In various regions, the sector's objective is determined upon needs. In most cases, it is the less abled and the economically disadvantaged.

Under the indicated dynamics, the operations are defined as the goals, structure, governance resources, and environment. In the economy, social enterprises engage with various industrial sectors, such as business activities and services. It is also a significant focus to work with the community and social services, social workers, education, and healthcare entities (Kerlin, 2006).

Various research entities (Kerlin, 2009) state that most countries have adopted the fee-forservice/product operational model for their social enterprises. Other forms implemented include the service-subsidisation model standard in Sweden and Hungary, the employment model common in Romania and Sweden, and the cooperative model, which has gained significance in countries such as Hungary and Romania (Kerlin, 2009). 


\subsection{Funding for Social enterprises}

Social enterprises operate to create social wealth and operate in environmentally responsible ways (Galera \& Borzaga, 2009). Their role in society is to provide services and products to the disadvantaged and the needy(Galera \& Borzaga, 2009). Given that the organisations operate on a nonprofit scheme, some are defined as profit social enterprises but are still involved in societal projects. The financing of such projects and operations requires funding.

Social enterprises are often founded on a business entity that provides income to the organisations (Lyon \& Owen, 2019). The businesses' proceeds are the major defining factor of the nonprofit enterprises since the surpluses generated are used to support the charity mission or the organization's objectives towards the community (Lyon \& Sepulveda, 2009). The model has become common in recent years with these organisations since the dependence on donations has become harder to source. The business approach has been a more sustainable and dependent move to affording social missions funds (Lyon \& Owen, 2019). The need to lower the dependency on the government and donor funding is the foundation of the continued adoption of innovation, experimentation, pro-activeness, risk-taking, and competitive aggressiveness among social enterprise businesses (Frumkin, 2009). For a while, this has indicated the continued desire to introduce new products and services to maximise profits, which will help fund (Frumkin, 2009).

The social enterprises' funding has long been based on donations and grants (Lyon \& Sepulveda, 2009). The governments in countries have always set aside funds to support social enterprises. The donations are also available from unions and international bodies to support the entities that help change society (Lyon \& Sepulveda, 2009).

Support causes are advanced towards various sectors that the donating bodies may be interested in changing. The funds are trickled down to particular social enterprises for redistribution(Lyon \& Owen, 2019). Individual donors have also played a significant role in funding, both locally and internationally(Kerlin, 2009). Profits from the fees in training and sales of products and services are also significant funding sources.

\subsection{Covid-19 and its effect on businesses}

The novel coronavirus pandemic came suddenly to the world, and due to its deadly nature, every sector would feel its impact. Covid-19 was declared as a global pandemic since it was very 
infectious and, at the same time, associated with a high and quick mortality rate (Biswas et al., 2020b). When protecting the population while monitoring the spread of the virus, various restrictive measures were put in place. The businesses and different institutions had to close to this effect.

The abrupt stopping of businesses has led to a long stall in the production and circulation of services in the economy (Yoosefi Lebni et al., 2020). According to Bartik (2020), reduced spending has also impacted businesses. The effect of the stopped processes in organisations was that most people were fired in the process, with a large percentage of job losses being recorded (Jordà, Singh, \& Taylor, 2020).

Without the anticipation of the long period in which the pandemic would ravage on, most businesses lost their ability to remain afloat (Jordà et al., 2020). The probability of most businesses having a contingency plan to last the long period in which the pandemic has persisted is deficient. With the organizations' financial fragility being defined differently across the sectors, most organisations could not remain in operation for long. The closure has, over time, led to a decline in business production and income (Yoosefi Lebni et al., 2020).

Even as the pandemic ravages on in various parts of the globe and most businesses have been greatly affected (Verma \& Gustafsson, 2020, p. 19). The resumption of operations must be a considerable activity for most businesses. The depletion of funds, the ignition of the organisational processes is bound to be tough. It is also a significant problem that business resumption is already tagged with new restrictive operation measures.

\subsection{The impact of covid-19 on social enterprises}

Reflecting on the effects upon other entities, it is also evident that the social enterprises have equally been affected. Even in the face of the pandemic, social enterprises' role is highlydemanding (Petrakis, 2020). Given that most of the sector entities are built towards helping the society through various problems and encounters, the impact was felt with a substantial burden tohelp alleviate the problems that arose (Petrakis, 2020).

At the basic level, the social enterprises were disrupted in the organizations' processes due to the restrictive measures implemented (Petrakis, 2020). The measures have affected business transactions and interactions based on the enterprises' social goals. Without a significant 
contingency to last the organisations worldwide, the globe has been on lockdown, the impacts on the running were likely paramount.

Social enterprises' funding relies heavily on donations, grants, and profits from the businesses dedicated to them (Yoosefi Lebni et al., 2020). Given that the pandemic was abrupt and the restrictions unexpected, the enterprises' significant source funding was disrupted. The organisations and individuals' ability to navigate and survive through the entire lockdown period was based on backup schemes for unexpected times (Schjoedt, Brännback, \& Carsrud, 2020). The financial muscle required to sustain an organization through a year of limited operation is unexpectedly large for social enterprises to possess (Schjoedt et al., 2020). Thus, with limited funding and blocked avenues, the impact was felt in various ways.

The UK has had a lengthy period of lockdown. The country's statistics on Covid-19 continue to rise each time (Balasubramanian, 2020, p. 19). Most social enterprises within the region have a high probability of being impacted. Research on different businesses indicates a deficiency plan to help businesses stay afloat (Lyon \& Owen, 2019). Challenges have affected various entities, and as a result, some are out of business. The research has also indicated that most organisations cannot revive back to the business at the end of the restrictions.

The research focuses on the impact of the pandemic on the pandemic on the social enterprises in Birmingham. The study results will help define the effects on social enterprises' operations and the impact on the funding. The study will define possible ways of addressing the challenges faced during the pandemic and offer recommendations for the future of operations. 


\section{METHODOLOGY}

\subsection{Introduction}

This research aims to evaluate the impact of the Covid-19 pandemic on the operations and funding of social enterprises in Birmingham, UK. Accordingly, the methodology section will discuss the methods that would be implemented to achieve the research objectives. Therefore, the methodology section will analyse the various research methodology components such as research strategy, research philosophy, research approach, data collection procedures, and data analysis. To achieve this the research has set aims and objectives in place.

\subsection{Research Onion}

Research by Saunders, Lewis, \& Thornhill (2007) defined a research onion as a detailed description of the stages involved in developing a research framework. (M. Saunders et al., 2007) He further stated that research highlights the different decisions when developing a research methodology. The figure below defines the research onion underlining the methodological layers that have been followed in this study.

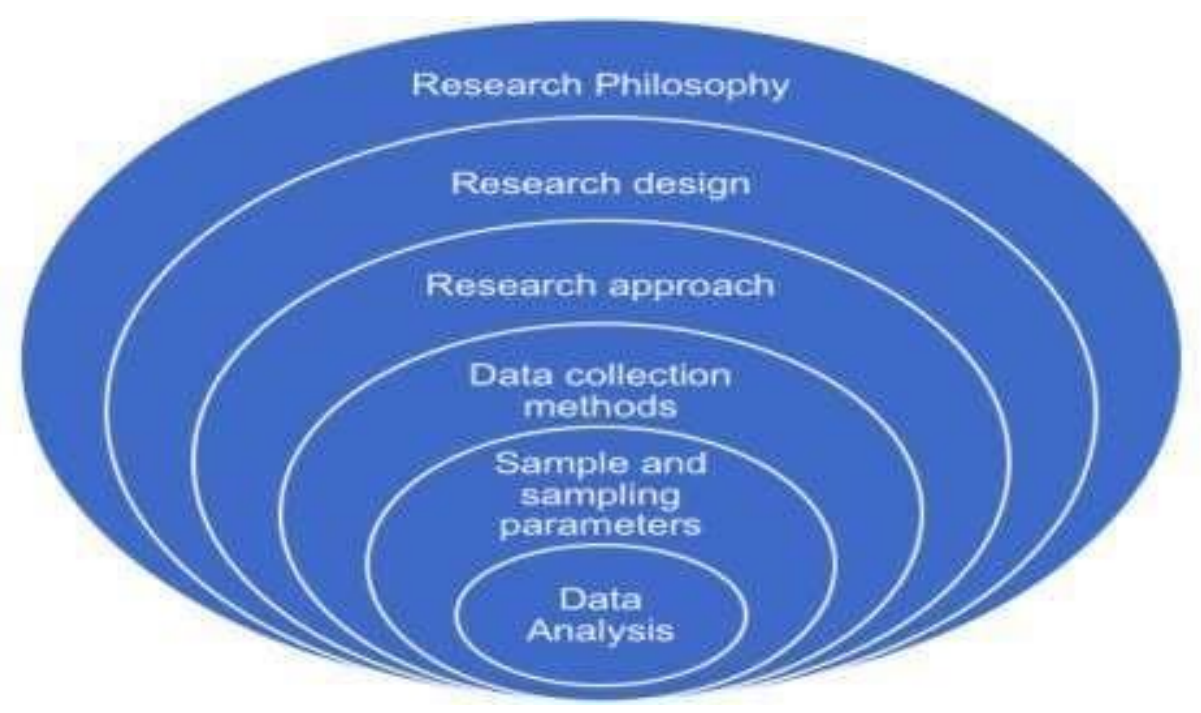

Figure 3. 1 Showing the Research onion

\subsection{Research Philosophy}

According to Corbin \& Strauss (2008), research philosophy puts together various assumptions and beliefs that determine the research design and methods of data collection that research would undertake. A study by M. N. Saunders, Lewis, Thornhill, \& Bristow (2015) highlighted the following three research philosophies: axiology, ontology, and epistemology. 
A study by Duberley, Johnson, \& Cassell (2012) described ontology as investigating whether the social phenomena under research exist independently of human perspective or a result. As a result, two social reality perspectives emerge objectivism and subjectivism (Easterby-Smith, 2012). Notably, this study will take the subjectivism approach because this study's results depend on human understanding, interpretations, and perspectives.

On the other hand, ontology consists of three different paradigms: positivism, interpretivism, and pragmatism. Mainly, this study follows the subjectivism model as it seeks to gain an in-depth insight into the impact of the Covid-19 pandemic on social enterprises' and their operations. It will be achieved by uncovering participants' perspectives on how the pandemic has affected the operations of social structures. Data is collected to gather individual perceptions on the phenomena through interviews considering the individual's viewpoints and experiences concerning the Covid-19 pandemic.

\subsection{Research Approach}

The most common research approaches include the deductive approach and inductive approach. Research is said to follow a deductive approach if the research begins with a developed hypothesis from an already established theory (Ketokivi \& Mantere, 2010). On the other hand, research is known to follow an inductive approach if it involves initial collection and observation of data to generate a theory (Ketokivi \& Mantere, 2010).

M.N. Saunders et al. (2015) termed a deductive approach as a top-down approach. In this case, the researcher works from a general perspective to a more precise point of view. In contrast, $\mathrm{M}$. N. Saunders et al. (2015) termed the inductive approach as a bottom-up approach. In this case, the researcher will work from a more specific perspective into broader generalizations. The figures below are a diagrammatic interpretation of both the inductive approach and the deductive approach. 


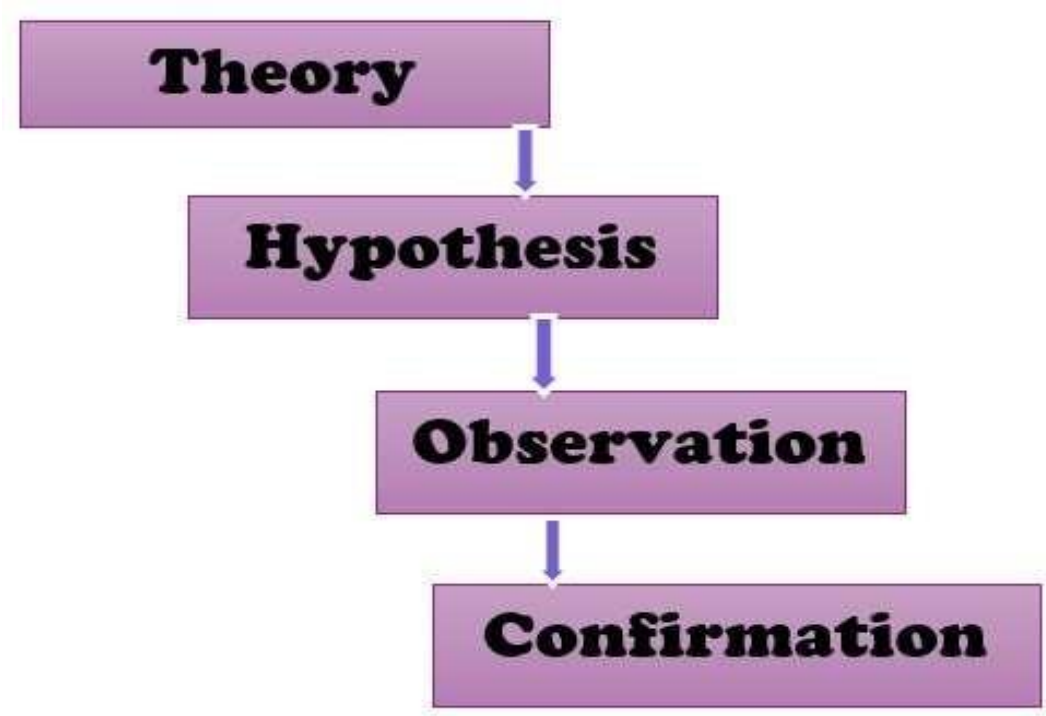

Figure 3. 2 Showing the Inductive Bottom-up approach (Ketokivi \& Mantere, 2010)

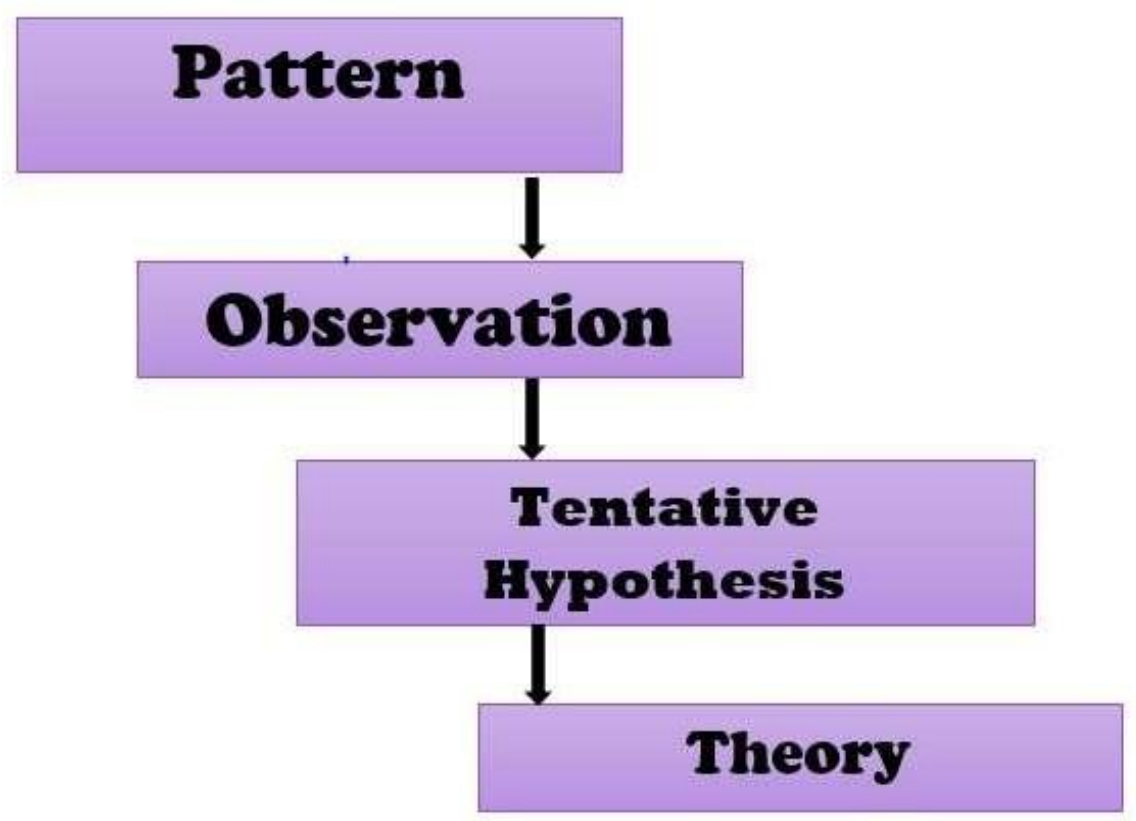

Figure 3. 3 Showing the top down approach (Ketokivi \& Mantere, 2010)

The inductive approach is exploratory during the initial stages of research, while the deductive approach works from a narrow perspective, mainly focusing on hypothesis testing (M.N Saunders et al., 2015). Therefore, this particular study will follow the inductive approach. It seeks to explore the Covid-19 phenomena and their impact on social enterprises by providing interview questions to relevant participants to gain insight based on the interviewees' interview responses. 


\subsection{Research Design}

The most common research designs used is that research projects include qualitative analysis and quantitative analysis. Qualitative analysis uses subjective judgment to comprehend phenomena from the perspectives of the relevant participants selected. In contrast, a quantitative analysis uses mathematical and statistical techniques to comprehend the phenomena under research (Choy, 2014).

Remarkably, this study would follow qualitative analysis to comprehend the participants' opinion regarding the phenomena under research. Moreover, qualitative analysis is imperative when the nature of the research questions requires exploration (M. N. Saunders et al., 2015). This research is exploratory, qualitative analysis is most suitable for this study.

\subsection{Data Collection}

The collection of data in this research will be executed through interviews. A set of selected relevant participants will be provided with a list of semi-structured interview questions. The respondents will be selected from various social entrepreneurship ventures in Birmingham, UK. The interview discussion session will entail 15 open-ended questions. The interview questions will vary from interview to interview depending on the participants' responses and area of expertise. The figure below gives a diagrammatic illustration of the data collection methods that are going to be used. 

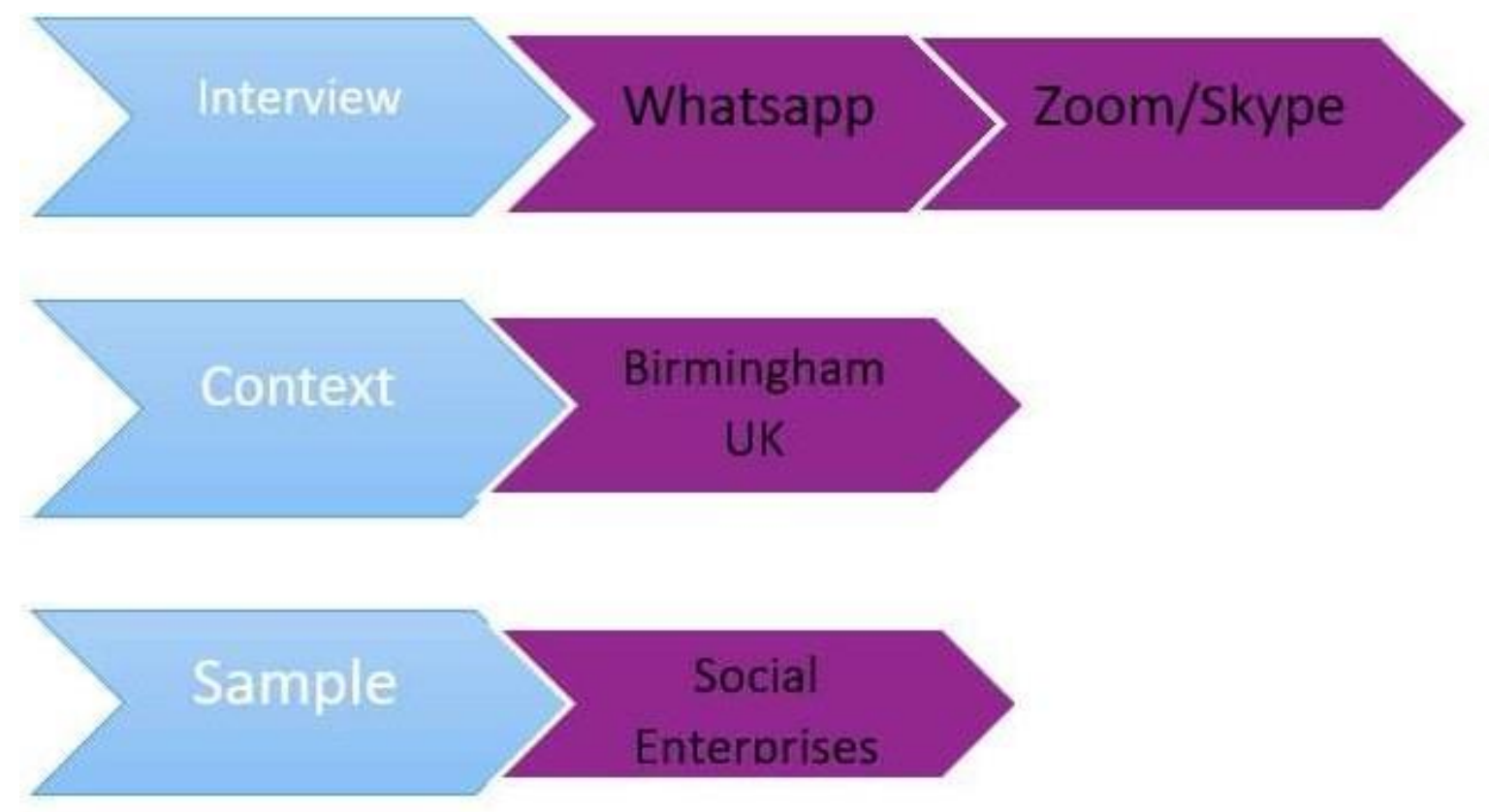

Figure 3. 4 Showing dimensions of data collection (Bell et al., 2018)

\subsection{Sampling Parameters}

Research by Bell \& Bryman (2007) defined two sampling techniques commonly used in research, including probabilistic sampling and non-probabilistic sampling. Probabilistic sampling entails random selection of respondents, allowing the researcher to make statistical inferences about the study sample (Bell \& Bryman, 2007). In probabilistic sampling, every member of a population has an equal opportunity to be selected in the study through a random process. On the other hand, non-probabilistic sampling entails non-random processes of selecting participants (Bell \& Bryman, 2007). M. N. Saunders et al. (2015) stated that probabilistic sampling is primarily used in quantitative analysis while non-probabilistic sampling is usually used in qualitative analysis. After all, qualitative analysis is not always concerned with generalizing the results to a larger population. Commonly used is a non-probabilistic sampling technique. Researchers use purposive sampling to select respondents with specific expertise in the phenomena underresearch (Bell \& Bryman, 2007).

Therefore, this particular study will follow the non-probabilistic purposive sampling method because the interview questions acted as a guideline in selecting the category of people to be sampled. The figure below is a diagrammatic representation of the sampling parameters used in this research. 


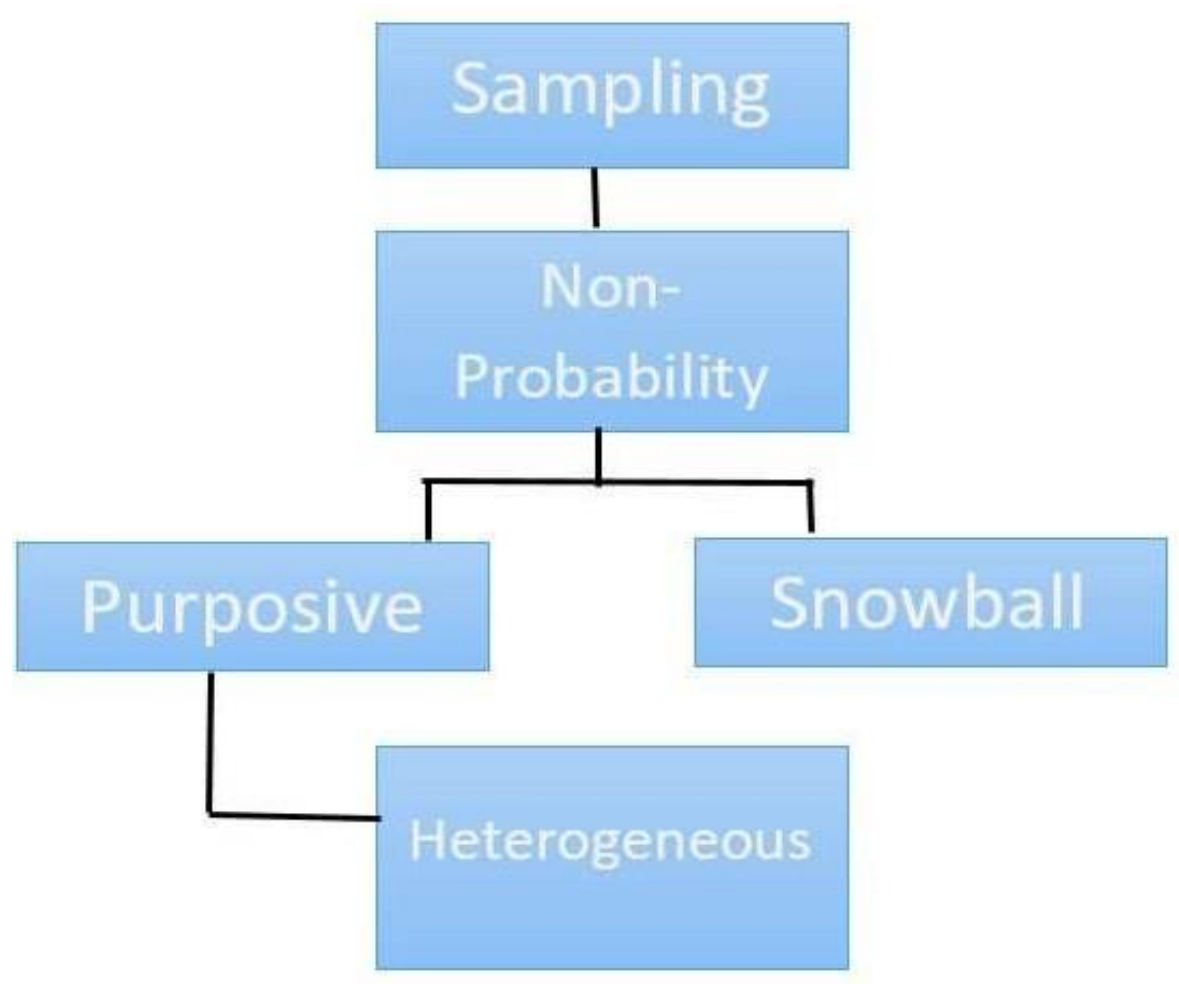

Figure 3. 5 Showing the Sampling parameters used (Bell et al., 2018)

\subsection{Data analysis}

Corbin \& Strauss (2008) defined analysis as the process of data interpretation and evaluation to derive purposeful results. Therefore, this research will use the thematic data analysis approach to do data analysis and interpretation. For this reason, the study will use a qualitative analysis data software known as "Nvivo" to do thematic analysis. Thematic analysis entails identifying, analyzing, and reporting themes and patterns within the data. Thematic data analysis is carried out through a systematic step-by-step iterative process using the qualitative data analysis software. The steps include:

I. Transcription of the interviews

II. Familiarization with the data and generation of keywords

III. Generation of codes

IV. The categorization of the codes into themes 
V. Comparison of the data with available literature

VI. Identifying patterns and relationships between categories and themes VII. Interpretation of the data

The figure below is a diagrammatic representation of the steps carried out in the thematic analysis.
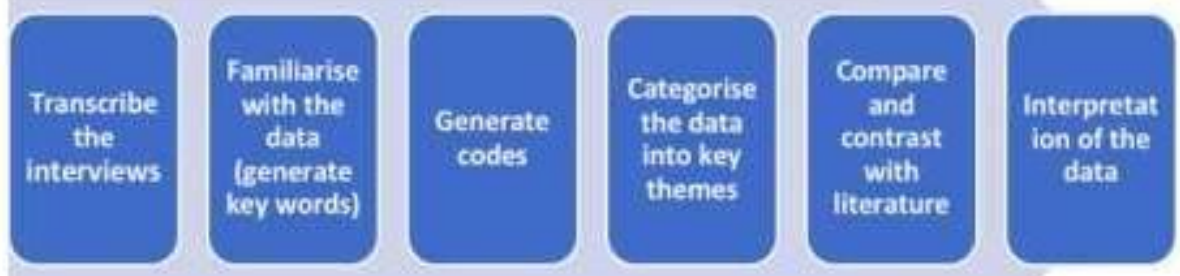

Figure 3. 6 Showing the process of thematic analysis (Corbin \& Strauss, 2008)

\subsection{Validity and Reliability}

Bell, Bryman, \& Harley (2018) emphasized the necessity of reliability and validity as essential measures in evaluating the accuracy, truthfulness, and trustworthiness of research. Testing for validity is vital in establishing if the results that have been obtained are significant to answer the research questions and achieve the research objectives (Bell et al., 2018). Testing for reliability entails testing the research method's ability to produce consistently similar results over the repetitive testing period (Bell et al., 2018).

One of the critical factors affecting validity and reliability is human error (Brink, 1993). Brink (1993) mentioned that the researcher risks data reliability and validity in qualitative analysis. A higher degree of error would result in less accurate results (Brink, 1993).

Therefore, this study will use three techniques recommended by (Brink, 1993) to minimise the risk of error to ensure the research methods' validity and reliability. 
- Extensive training of the researcher as interviewers before data collection

- Researcher Spending enough time with the interviewee before data collection starts

- The researcher assesses and enhances a relationship with the interviewees to move from a stranger to a friendlier person during the research process using the stranger-to-friend model (Brink, 1993).

Reliability and validity are dependent on four aspects: creditability, dependability, transferability, and conformability (Guba \& Lincoln, 1994). To ensure that the four aspects will be taken into consideration throughout the research. Much focus will be put to find a match between research questions, methods, and theory. During the research, the theory evolved, and the research questions will be modified to address the subject matter appropriately. In addition to that, the data sample will be matched with the research area and will consist only of respondents who have a solid connection to social enterprises. Accordingly, this will facilitate a close bond between the data and the research topic, making the research process and proceed in one direction.

\subsection{Ethical Considerations}

Ethical considerations are essential as they ensure the general public's accountability by protecting the study's subjects (Connelly, 2014). Ethical considerations are essential as they support the values required for collaborative work, such as mutual respect, fairness, and not harming others (Connelly, 2014). Before conducting the research, individual consent will be obtained from the subjects. After that, the participants will be provided with information regarding the dissertation, purpose, and significance. Moreover, the participants will be informed that their participation in the interviews would be entirely voluntary. The respondents will also be informed that their identities would remain anonymous, and no unauthorized party will have access to the respondent's information as it would be private and confidential. 


\section{RESULTS AND DISCUSSION}

\subsection{Introduction}

To achieve the objectives of this research project, the study conducted interviews with relevant stakeholders in the social enterprise sector in Birmingham to generate insight into the impact of covid-19 in the social enterprise sector. After the interviews were carried out, qualitative analysis was carried out to unearth opinions, perspectives, experiences and thoughts of participants regarding the interview questions. Mainly, the research project put together the data collected through the semi-structured interviews, identified possible patterns within the data set andanalyzed it through thematic analysis, capturing essential information in the collected data that canbe used to answer the hard research questions and achieve the study objectives. After the collectionof the data, the study developed initial relevant codes depending on the data. After that, the researchers sorted the different developed codes into themes and collating the potent coded extracts within the identified themes. This section of the research presents the findings from the analysis and a detailed discussion of the results produced.

\subsection{Response Rate}

Following this, the research project had initially targeted nine respondents to take up the interview questions. Targeted respondents had a direct and indirect interest in social enterprises such as employees, beneficiaries, funders, local leaders, owners, entrepreneurs, and social enterprises. Respondents included respondents who live or work in the city of Birmingham in the UK. Interviews addressed the respondent's perspective on Covid-19 and its effects on the operations and funding of social enterprises. Out of the nine targeted respondents, one respondent did not participate in the interview process for fundamental reasons. Eight respondents participated in the research process, which is an $89 \%$ response rate. An $89 \%$ response rate is an above-average response rate, making the eight interviews usable and sufficient for practical qualitative analysis.

\subsection{Demography analysis}

In the preliminary analysis, the study analyzed the selected population based on demographic factors such as age, gender, and stakeholder type. Demographic analysis is essential as it provides data regarding the research respondents and helps the researcher determine whether the research participants represent the target population for generalization purposes. 


\subsubsection{Gender}

Respondents were expected to state their gender in the preliminary analysis. Out of the eight participating respondents, $63 \%$ were male, while $37 \%$ were female. Admittedly, the gender distribution of the data sample indicates a gender balance in the selected sample. The figure below summarizes the above data.

\begin{tabular}{|l|l|l|}
\hline Gender & $\mathrm{N}=6$ & $\mathrm{~N} \%$ \\
\hline Male & 5 & $63 \%$ \\
\hline Female & 3 & $37 \%$ \\
\hline Total & 8 & $100 \%$ \\
\hline
\end{tabular}

Table 4. 1 Showing Gender Distribution of the respondents

\section{Pie-chart showing participant's gender distribution}

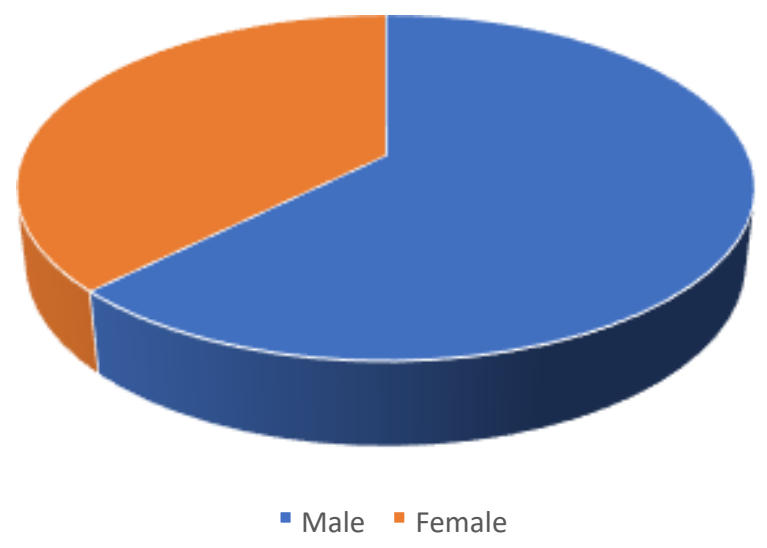

Figure 4. 1 Pie chart showing gender distribution of the respondents

\subsubsection{Age}

The participants were also requested to state their age so that the research could gain insight into the respondents' age composition. $17 \%$ of the respondents were between the ages of 25 and 35 , while $50 \%$ were between the ages of 35 and 45, while $33 \%$ were between 45 and 55 years. There is an outstanding balance in the age distribution of the respondents for individuals of different age groups. The figure below is a summary of the above data. 


\begin{tabular}{|l|l|l|}
\hline Age group & N & N\% \\
\hline $25-35$ & 1 & $13 \%$ \\
\hline $35-45$ & 4 & $50 \%$ \\
\hline $45-55$ & 3 & $37 \%$ \\
\hline Total & 8 & $100 \%$ \\
\hline
\end{tabular}

Table 4. 2 Showing the age distribution of the respondents

\section{Pie-chart Illustrating the age distribution of the respondents}

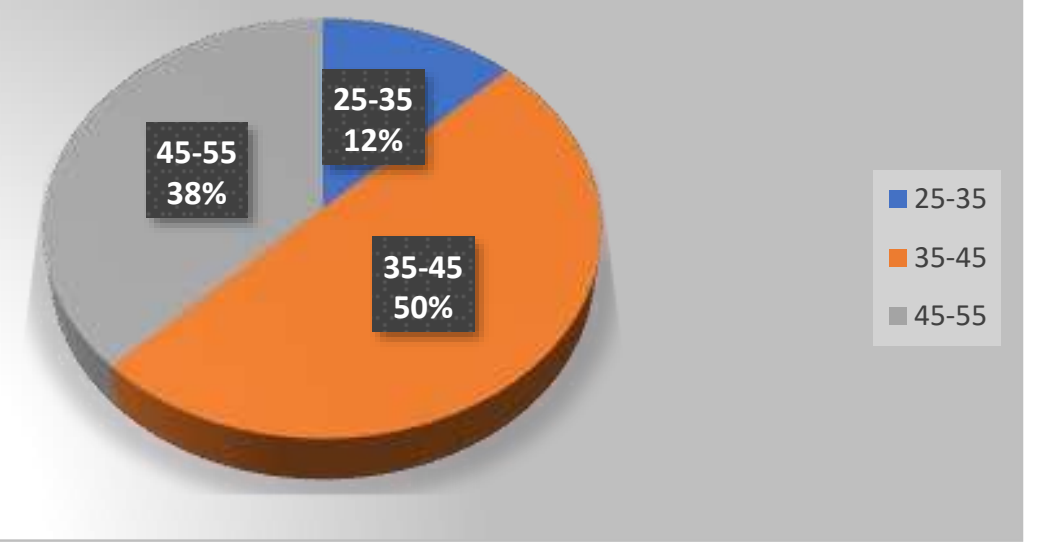

Figure 4. 2 Showing age distribution of the respondents

\subsubsection{Stakeholder Position} The respondents were also required to state their stakeholder position in social enterprises. Out of the eight respondents, $12.5 \%$ of the respondents were employees of social enterprises. In contrast, $12.5 \%$ of the respondents were customers of social enterprises, while $75 \%$ of the respondents were managers and directors of social enterprises.

\begin{tabular}{|l|l|l|}
\hline Stakeholder Position & $\mathrm{N}$ & $\mathrm{N} \%$ \\
\hline Employee & 1 & $12.5 \%$ \\
\hline
\end{tabular}




\begin{tabular}{|l|l|l|}
\hline Customer & 1 & $12.5 \%$ \\
\hline Owners \& Managers & 6 & $75 \%$ \\
\hline Total & 8 & $100 \%$ \\
\hline
\end{tabular}

Table 4. 3 Showing the stakeholder position of the respondents

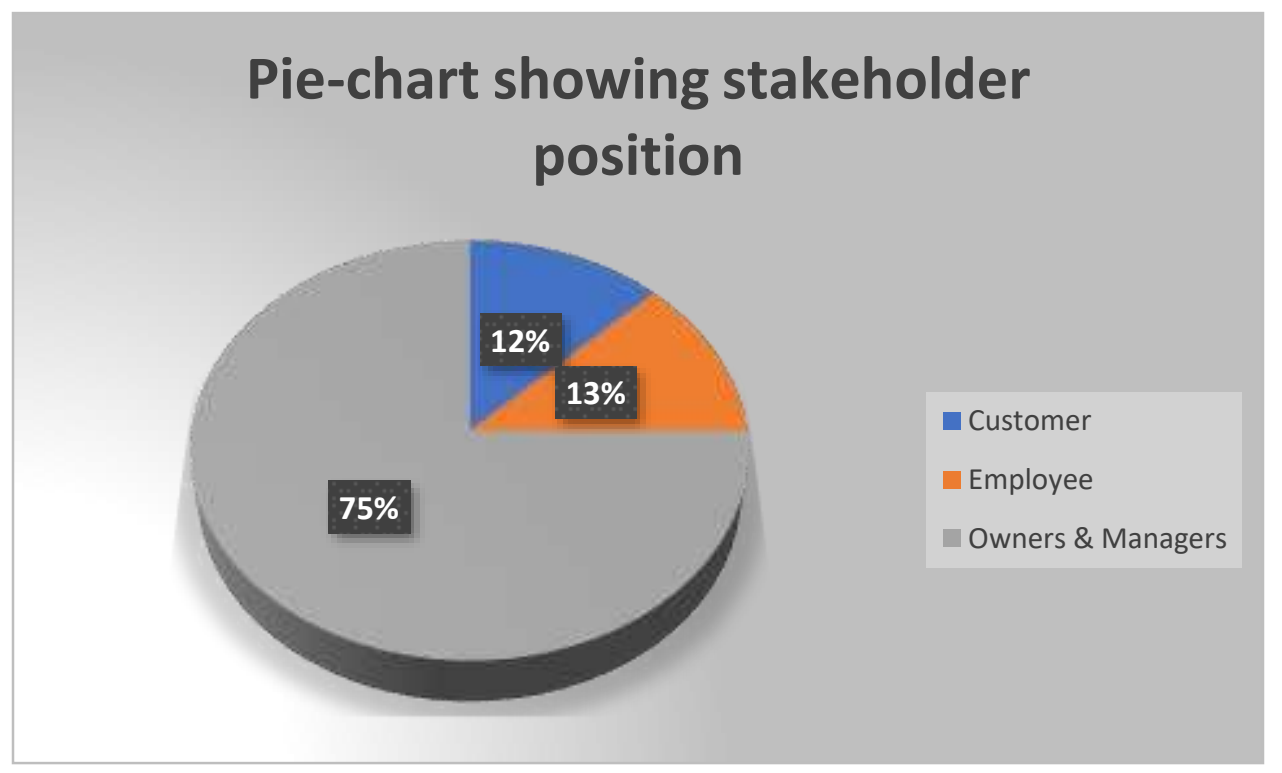

Figure 4. 3 Pie chart illustrating stakeholder position of the participants

Note: In the thematic analysis that follows, respondent 1 to 6 were entrepreneurs, respondent 7 was a customer, respondent 8 was an employee.

\subsection{Thematic analysis}

Thematic analysis was carried out to develop themes and subthemes for the research. As a result of thematic analysis, a set of preconceived themes are identified through an inductive approach. Induction of thematic analysis is carried out to extract all possible patterns meaningful to the research objectives and questions.

\subsubsection{Theme 1: Role of social enterprises}

First and foremost, the interview questions required the respondents to give their perspectives on the role of social enterprises in society. Most of the respondents appreciated the 
fact that social enterprises have played a critical role in transforming communities. Social enterprises in Birmingham have implemented innovative and value-driven economic practices that are built around a social purpose. Therefore, the innovative projects have brought together policymakers, citizens, small market enterprises, colleges, and relevant stakeholders to support Birmingham communities. Respondents have also hinted that social enterprises have developed new market gaps and unlocked new market niches that traditional enterprises initially took. It was also noted that social enterprises had developed alternatives ideas of conducting economic activities that have inspired other economic players to act differently.

Respondent 1

"In our organization, we have embraced a more sustainable method of production of energy. By exploring renewable sources of energy, we have inspired the energy transition in Birmingham by encouraging renewable energy sources and promoting affordable citizen-based energy systems."

Respondent 2

"In our social enterprise, we have created cooperative supermarkets that are member-owned whereby the consumers are also owners of their cooperatives as opposed to the traditional shop owner-consumer relationship. This has helped promote purchasing local and organic foods at affordable prices to the local communities."

Respondent 3

"Our organization is not entirely based on profit maximizations. Our main focus is promoting social cohesion, offering services at affordable prices, providing employment opportunities and promoting local culture in our communities."

According to the respondents, social enterprises are beneficial to society during the Covid19 pandemic in two significant spheres.

I. Economic sphere

Social enterprises facilitate local economic development by increasing economic activity and creating employment opportunities for less privileged community members who are often excluded from the labour market. As a result, this has played a critical role in stimulating economic 
growth. Moreover, the respondents hinted that social enterprises had stimulated economic growth while instilling responsible community practices and an inclusive and sustainable model.

\section{Society sphere}

Respondents highlighted that social enterprises enhance social cohesion in the community. They hinted that most social enterprises promote social cohesion by reducing inequalities by providing goods and services to vulnerable community members at affordable prices and fostering a sense of community by involving citizens in different ways, primarily through volunteering activities.

\subsubsection{Theme 2: Risk}

The emergence of the Covid-19 pandemic has generated many risks for social enterprises, entrepreneurs, and business people that were unprecedented. According to the interviews, risk management appeared as a critical management response concerning the emergence of the Covid19 pandemic. Most of the respondents highlighted that Covid-19 had posed a significant risk to them in their different capacities. Therefore, the emergence of the Covid-19 pandemic has presented the need for risk management for sustainability of social enterprises during the Covid19 pandemic. From the interview responses, there emerged two types of risks that the participants considered significant. The three risks included financial risk and market risk.

All the respondents, regardless of their stakeholder position, highlighted that the Covid-19 pandemic had affected their financial position. Managers stated that Covid-19 had caused a significant decline in the demand for products and services, leading to a reduction of cash generation in businesses and a steep drop in corporate earnings. Disruption of the financial position of many businesses in Birmingham has been captured in cash flow ratios in the social enterprises in Birmingham. Many of the respondents hinted that the Covid-19 pandemic had reduced the number of opportunities for social enterprises to acquire funding through grants, fellowships and support from donations. Admittedly, this is because most of the grants during the pandemic period have been redirected to the Covid-19 response measures in the provision of personal protective equipment, the search for a vaccine, support to economically deprived regions, among many other areas. 
Respondents noted that the main problem is identifying sources of funding during the time of the pandemic at the time that equity funding and start-up funding has reduced. A reduction in financial disposition has become a great challenge for social enterprises as opposed to commercial enterprises as their mission to operate a business and at the same time initiate social transformation makes some investors skeptical about investing in them. Here are some of the participants' responses with regards to the financial risk that the Covid-19 has posed on them.

\section{Respondent 3}

"With the emergence of the Covid-19 pandemic, we have lost many of our customers, and this has greatly affected our business. As a result, when we compare our level of income right now to the period before the pandemic, our level of income right now is way low because of the reduction in the number of our customers."

\section{Respondent 4}

"We started this investment in early 2020, and we had expected that by the end of the year 2020, we would have reached a break-even point. Unfortunately, with the covid-19 pandemic, we were unable to reach our set business goals. Therefore, we are trying to shift our strategy in order to survive."

\section{Respondent 5}

"This social enterprise is not entirely about making profits; cash flows are essential in enabling us to cover our expenses and fixed costs. As a result of the Covid-19 pandemic, there has been a significant deterioration in revenue and cash flows as they do not go as smoothly as before. This is making us strain in the delivery of our services."

From the responses, the researchers concluded that the Covid-19 pandemic also posed a personal financial risk to individuals who cannot access the services provided by the social enterprises as a result of the pandemic. Here are some of the responses showing how the Covid19 pandemic has posed a personal financial risk to potential customers of social enterprises. 


\section{Respondent 8}

"Due to the restrictions set by the government as a result of the Covid-19 pandemic, I lost my job. Therefore I had to survive on online jobs. When I lost my job, I had little disposable income to meet my day to day needs and even cover my house loan and back payment on taxes. As a result, I am unable to visit my microfinance institution to ask for another loan with the pending loans that I have."

\section{Market risk}

According to the responses, the Covid-19 pandemic has exposed many businesses to market risk in two ways.

I. Through decrease of supply in the labour market

II. Through demand-supply imbalance

\section{Supply in the labour market}

Labour supply shocks have been dominant with the emergence of the Covid-19 pandemic. The Covid-19 infection has greatly affected individuals in the market place making them unable to work, causing a decline in the labour supply. Some of the workforces have reportedly succumbed to the Covid-19 infection. Respondents commented that the Covid-19 pandemic has reduced labour supply due to mortality, morbidity due to infection and morbidity due to the need for care for affected family members. The Covid-19 contingent measures of isolation and social distancing have also contributed to the decline in the availability of labour in the economy.

\section{Respondent 6}

"Some of my staff contracted the covid-19 infection around June last year, which forced us to close down our offices due to the transmission rate of Covid-19. We, therefore, chose to seek alternatives of working such as working from home."

\section{Demand supply imbalance}

The emergence of the Covid-19 pandemic has caused a significant shift in demand and supply in social enterprises. Conventionally, given constant demand, a decrease in the supply of goods and services would lead to inflation, whereas given constant supply, a demand reduction would lead to disinflation. From the interview responses, most of the social enterprises were 
affected by the reduction in demand for services since most customers could not purchase some of the products as customers had shifted their focus to more basic goods and services.

\section{Respondent 7}

"With the emergence of the Covid-19 pandemic, it was imperative to focus my finances on necessities of food and housing so that my family would survive during this great turmoil."

\section{Respondent 5}

"Business in customer service has suffered a great blow from this Covid-19 pandemic because due to the containment measures, people are not just seeking to purchase beauty products because they are not a necessity."

Moreover, the closure of non-essential services and lockdowns has contributed to decreased goods and services.

Respondent 3

"Since the universities been shut for a while now and students do not come to school any more, I lost a huge number of customers because students were my primary source of income."

\subsubsection{Theme 3: Operational Change}

At the onset of the Covid-19 pandemic, change in companies and organisations has been inevitable. Change in an organization has been imperative in order for businesses to adapt to a Covid-19business environment. However, the respondents also commented that initiating operational change is a big challenge as it involves grand procedures. An operational change must first be presented as a proposal, put under consideration, evaluated and agreed upon before it is actualized. Most respondents hinted that change in operational activities might be time-consuming since it would take a long time for the strategic change plan to be approved. Most of the changes that the participants considered significant included Cost management-related changes and alternative services.

\section{Cost management changes}

According to the respondents, most of the social enterprises have initiated measures to reduce costs and risks involved in business to manage the production and profitability of the 
businesses. Many of the respondents highlighted that the Covid-19 pandemic had forced their companies to tighten their budgets and eliminate needless business expenses. Organisations in Birmingham took control of the business costs; strategically, this included cost-cutting in the short term and long-term budgets, reduced expenses, reduced outsourcing and hiring, delay and cancellation of non-essential goods and services. They considered a work from home program to reduce travel expenses, considering adjusting schedules from full time to part-time and retrenching employees.

\section{Respondent 1}

"The reduction of profits in our organization, we were forced to cut business costs in order to adapt to the new normal. We have tried our best to ensure that we perform all processes on our own “

Respondent 6

"We decided to limit our staff to have the minimum number of people available to do the required to maximise our employees' potential. Our company also maximized our employees' potential by reducing the number of hired employees and using the employees within the organization."

\section{The offering of alternative services}

As a result of the Covid-19 pandemic, most social enterprises had to look out for alternative operation methods in compliance with the Covid-19 containment measures. Various respondents highlighted that few social enterprises resorted to offering their services through digital platforms. offering takes away services, home delivery, advertisements through social media.

\section{Respondent 3}

"The emergence of the Covid-19 pandemic forced us to focus on embracing the digital technology in our operations. If it was not the pandemic, we could not have embraced some of these different models of business operations."

\subsubsection{Theme 4: Government Support}

Social enterprises in Birmingham received much support from the government during the time of the Covid-19 pandemic. Respondents noted that the Birmingham city council implemented policies that have helped the social enterprises protect their financial security. Some of the measures put in to protect the financial security of social enterprises include providing upfront 
payments of existing grants, rolling over recurrent grants to subsequent years without the need for formal applications. For this reason, the Birmingham city council tried its best to extend contracts that were due for expiry. Respondents also noted that the Birmingham city council played a critical role in lobbying the central government of the great work which has been done by the social enterprise sector, especially during the time of the pandemic and also made sure that the government provided support for social enterprises through provision of funding, resources and recognition to enable them to work efficiently during the Covid-19 pandemic.

\section{Respondent 4}

"The government was grateful for the great work done by the social enterprise sector, especially during the time of the pandemic for helping people across Birmingham through these unprecedented times. In a statement to the voluntary community and enterprise sector, the government commended social enterprises for working together with the communities to keep the communities safe. They also assured us full support in managing the difficult challenges like a spike in demand for services, potential reduction in staffing levels and fundraising capacity. The government promised to support us we continue to support more vulnerable people in our communities."

\subsubsection{Theme 5: Future of social enterprises}

The emergence of Covid-19 has been facilitated a lot of changes in economic activities and the functioning of society. Therefore, policymakers must think of alternative ways of protecting the citizens of Birmingham and deliver the appropriate services more efficiently. Social enterprises have been instrumental in mitigating the effects of the pandemic.

Respondent 7

"Social enterprises have played a critical role in ensuring sanitary issues in the community and have also been a trusted partner in ensuring a better allocation of resources in the provision of goods and services needed to address immediate concerns."

The emergence of the covid-19 pandemic is a wake-up call for policymakers to develop a more inclusive and sustainable future. It is a call to rethink the balance of objectives of efficiency and resiliency in different areas of economic and social systems.

\section{Respondent 1}


"Post Covid-19 measures need to be put in place in order to change the Covid-19 crisis into an opportunity to enhance the better livelihood of the community and stimulate innovation."

\section{Respondent 4}

"During the pandemic, social enterprises can release their full potential through facilitating the transition towards more resilient societies through its principles of solidarity, cooperation and social impact."

Moving forward, social enterprises need to take center stage and inspire responsible activities in the mainstream economic sector by incorporating economic activities with environmental and social activities. Policymakers should implement policies that promote social innovation and cooperation to enhance the impact of social enterprises in social transformation.

\subsubsection{Discussion}

The main challenge of the Covid-19 crisis to social enterprises is that most of the social enterprises utilized most of their resources in the emergency response that has affected their operational capacity due to short term liquidity problems (Farhoud et al., 2021). Since it has been noted within the interview responses, the social enterprises need much support from the government, and their situation would worsen without sufficient support from the government. One of the critical issues that have affected most social enterprises is the drop in activity due to the Covid-19 crisis (Phillipson et al., 2020). Social enterprises have experienced a reduction in cash flows, drop in sales, disruptions with personnel management. As a result, social enterprises have lost a considerable amount of their projected revenues (Phillipson et al., 2020). Therefore, it is essential for policy markets to implement measures that will enhance the sustainability of social enterprises during the Covid-19 pandemic and even in the post-Covid-19 era.

Policymakers should facilitate this social transformation by providing financial resources to social enterprises that promote social innovation and adopt new business models. The government should make sure that it creates an environment that encourages social innovation by funding the innovation projects suggested by social enterprises. Moreover, the government should also fund projects that facilitate the community's transformation to a green, inclusive and sustainable community. 


\section{CONCLUSION}

\subsection{Introduction}

Chapter 5 presents a summary of the results and discoveries discussed in Chapter 4 above and concludes from the research findings. Moreover, this chapter also seeks to suggest recommendations for further research in this area of study.

\subsection{Summary of the findings}

For the most part, this study aimed to analyse the effects of Covid-19 on the operations and funding related to Social enterprises in Birmingham, UK. Notably, the nature of the subject under investigation required qualitative analysis to analyse the various experiences, perspectives, and thoughts of the research participants. The respondents were either employees in Social enterprises, customers of social enterprises, managers and directors of social enterprises. Responses from the participants regarding the effects of COVID 19 on the operations and funding of social enterprises were sufficient to generate a credible conclusion and practical recommendations.

Admittedly, the research established that the stakeholders in social enterprises were not prepared for the COVID 19 pandemic and its consequences. Social enterprises in Birmingham had not pre-established disaster management programs to counter the consequences of the pandemic. As a result, most of the social enterprises utilized most of their resources in the emergency response towards the pandemic. Therefore, this resulted in short term liquidity problems in the social enterprises. The core responsibility of social enterprises in the society of implementing innovative and value-driven economic practices was affected in the different scenarios the respondents derived their perspectives from.

Thematic analysis of the research findings unearths many risks that social enterprises were exposed to by the COVID 19 pandemic. First and foremost, all the respondents highlighted that their financial positions were affected. The significant decline in the demand for goods and services during the pandemic reduced the cash generation in the businesses.

According to the responses, this study established two significant sources of funds for social enterprises: profits/retained earnings from their business and grants from governmental and nongovernmental institutions. As a result of the pandemic, grants became a great challenge to secure because most of the grants and donations were redirected towards managing the COVID 19 situation in providing relief services to the worst-hit communities, provision of COVID 19 
protective wear, among other prioritized initiatives. Therefore, a substantial financial risk was posed on these social enterprises in Birmingham.

One of the key findings of this research is that the COVID 19 pandemic exposed the enterprises to a risk of shortage of labour supply and demand-supply imbalance. Admittedly, the social nature of social enterprises exposed workers to the COVID-19 infection, thus making them unable to work. COVID 19 contingent measures of isolation also contributed to the unavailability of the labour force at their work stations.

The market risk presented itself in the form of shifts in demand and supply patterns in social enterprises. From the interview responses, the reduction of demand for goods and services affected most social enterprises since the customers had shifted their focus to essential goods and services for survival. Ban of operations for non-essential services also contributed to the decrease in demand for some goods and services, for instance, service providers around schools and universities. Decrease in demand, shortage of labour supply, and other financial risks led to losses from projected revenue.

It was also observed that the onset of the COVID 19 pandemic forced enterprises to restructure their organization to suit the new norm, which was a great challenge for most of the social enterprises. Due to the already low cash disposition, most respondents highlighted that their companies had to apply stringent cost-efficiency models to eliminate unnecessary expenses and still achieve a sustainable profit margin. These included laying off some employees and working from home to cut travel expenses. On the other hand, some respondents highlighted that some social enterprises sought alternative ways of operation to suit the new COVID 19 containment measures like service providing exclusively through digital platforms and offering take away services.

Respondents noted that the Birmingham City council supported social enterprises by helping protect their financial security, extending contracts due for expiry and lobbying the central government for the great work that the social enterprise sector has done. Moreover, the government also supported them through the provision of resources and recognition.

Admittedly, this research shows that social enterprises have been instrumental in mitigating the effects of the COVID 19 pandemic, including posing as the trusted partner in ensuring a better 
allocation of resources in the provision of goods and services needed to address immediate concerns.

\subsection{Recommendations}

Due to the nature of the Covid-19 pandemic, social enterprises must adapt to the new way of life. Action plans for social enterprises to facilitate the transition towards more resilient societies through its principles of solidarity, social impact, and cooperation need to make. Embracing and realizing the full potential of social enterprises is very instrumental in the bid to change the COVID 19 crisis into an opportunity and enhance better livelihood in the community and stimulate innovation and exploring economic activities.

Players in social enterprises should accept to take pay cuts. The goal of profit maximization in the businesses has to be put on hold. Businesses should instead intend to purely serve the various goods and services in the affected communities. However, this does not ignore the need to meet operational costs of the businesses, which calls for a cost-profit balance strike to achieve a winwin situation between them and the now low income-earning consumers.

Relevant policymakers should develop more inclusive and sustainable approaches as they handle the current situation and have an eye on the future if they need to cushion against similar occurrences. Moreover, they should implement policies that promote social innovation and cooperation to enhance the impact of social enterprises in social transformation. In addition to that, the government can continue supporting social enterprises and their activities through issuing grants and create a conducive business environment for the stakeholders in the social enterprise sector. 


\section{REFERENCES}

1. Adam, S. (2004). The emergence of social enterprise (Vol. 4). Psychology Press.

2. Adams-Prassl, A., Boneva, T., Golin, M., \& Rauh, C. (2020). Inequality in the impact of the coronavirusshock: New survey evidence for the UK. Faculty of Economics, University of Cambridge.

3. Aruru, M., Truong, H.-A., \& Clark, S. (2021). Pharmacy Emergency Preparedness and Response (PEPR): A proposed framework for expanding pharmacy professionals' roles and contributions to emergency preparedness and response during the COVID-19 pandemic and beyond. Researchin Social and Administrative Pharmacy, 17(1), 1967-1977. Elsevier.

4. Bailey, N., Kleinhans, R., \& Lindbergh, J. (2018). An assessment of community-based social enterprisein three European countries. Power to Change.

5. Balasubramanian, M. (2020). Covid 19-The New Age Pandemic. Notion Press.

6. Bartik, A. W., Bertrand, M., Cullen, Z., Glaeser, E. L., Luca, M., \& Stanton, C. (2020). The impact of COVID19 on small business outcomes and expectations. Proceedings of the National Academy of Sciences, 117(30), 17656-17666. National Acad Sciences.

7. Bell, E., \& Bryman, A. (2007). The ethics of management research: An exploratory content analysis.

a. British journal of management, 18(1), 63-77. Wiley Online Library.

8. Bell, E., Bryman, A., \& Harley, B. (2018). Business research methods. Oxford university press.

9. Biswas, A., Bhattacharjee, U., Chakrabarti, A. K., Tewari, D. N., Banu, H., \& Dutta, S. (2020a). The emergence of Novel Coronavirus and COVID-19: Whether to stay or die out? Critical reviewsin microbiology, 46(2), 182-193. Taylor \& Francis.

10. Biswas, A., Bhattacharjee, U., Chakrabarti, A. K., Tewari, D. N., Banu, H., \& Dutta, S. (2020b). The emergence of Novel Coronavirus and COVID-19: Whether to stay or die out? Critical 
reviewsin microbiology,

a. 46(2), 182-193. Taylor \& Francis.

11. Bittihn, P., Hupe, L., Isensee, J., \& Golestanian, R. (2021). Local measures enable COVID-19 containment with fewer restrictions due to cooperative effects. EClinicalMedicine, 100718. Elsevier.

12. Brink, H. I. (1993). Validity and reliability in qualitative research. Curationis, 16(2), 35-38.

13. BSSEC. (2014, March 12). Social enterprise in Greater Birmingham. BSSEC. Retrieved March 2, 2021, from https://bssec.org.uk/social-enterprise-in-greater-birmingham/

14. Bull, M., \& Ridley-Duff, R. (2008). Social enterprise as a socially rational business. InternationalJournal of

a. Entrepreneurial Behavior \& Research. Emerald Group Publishing Limited.

15. Chowell, G., \& Mizumoto, K. (2020). The COVID-19 pandemic in the USA: What might we expect? 16. The

a. Lancet, 395(10230), 1093-1094. Elsevier.

17. Choy, L. T. (2014). The strengths and weaknesses of research methodology: comparison and complimentary between qualitative and quantitative approaches. IOSR Journal of Humanitiesand Social Science, 19(4), 99-104.

18. Connelly, L. M. (2014). Ethical considerations in research studies. Medsurg Nursing, 23(1), 54-56.

a. Jannetti Publications, Inc.

19. Corbin, J., \& Strauss, A. (2008). Strategies for qualitative data analysis. Basics of Qualitative Research.

a. Techniques and procedures for developing grounded theory, 3. Sage Publications Inc.

20. Crosby, A. W. (2003). America's forgotten pandemic: The influenza of 1918. Cambridge UniversityPress.

21. Defourny, J. (2013). Third sector. Handbook on the economics of reciprocity and social enterprise. 
a. Edward Elgar Publishing.

22. Defourny, J., \& Nyssens, M. (2006). Defining social enterprise. Social enterprise: At the crossroads ofmarket, public policies and civil society, 7, 3-27.

23. Defourny, J., \& Nyssens, M. (2008). Social enterprise in Europe: Recent trends and developments.

a. Social enterprise journal. Emerald Group Publishing Limited. 
24. Defourny, J., \& Nyssens, M. (2014). The EMES approach of social enterprise from a comparative perspective. Social enterprise and the third sector: Changing European landscapes in a comparative perspective, 12, 42-65. Routledge London.

25. Doherty, B., Thompson, J., \& Spear, R. (2006). Social entrepreneurship: A different model?

a. International journal of social economics. Emerald Group Publishing Limited.

26. Dorigo, L. (2010). Social enterprise and stakeholder governance: A comparison of the CSR performancein single-stakeholder and multi-stakeholder structures. Università Ca’Foscari Venezia.

27. Duberley, J., Johnson, P., \& Cassell, C. (2012). Philosophies are underpinning qualitative research.

a. Qualitative organisational research: Core methods and current challenges, 15. Sage Los Angeles, The USA.

28. Easterby-Smith, M. (2012). Management research: Mark Easterby-Smith, Richard Thorpe and PaulJackson. Los Angeles ; SAGE,

29. Frumkin, P. (2009). On being nonprofit: A conceptual and policy primer. Harvard University Press.

30. Galera, G., \& Borzaga, C. (2009). Social enterprise: An international overview of its conceptual evolution and legal implementation. Social enterprise journal. Emerald Group PublishingLimited.

31. Gatto, M., Bertuzzo, E., Mari, L., Miccoli, S., Carraro, L., Casagrandi, R., \& Rinaldo, A. (2020). Spreadand dynamics of the COVID-19 epidemic in Italy: Effects of emergency containment measures.Proceedings of the National Academy of Sciences, 117(19), 10484-10491. National Acad Sciences.

32. Ghosh, A., Nundy, S., Ghosh, S., \& Mallick, T. K. (2020). Study of COVID-19 pandemic in London(UK) from the urban context. Cities, 106, 102928. Elsevier.

33. Guba, E. G., \& Lincoln, Y. S. (1994). Competing paradigms in qualitative research. Handbook ofqualitative research, 2(163-194), 105. California, Sage Publications. 
34. Hatch, J. (2020, April 8). How is Covid-19 affecting NGOs' finances and operations? Bond. Text,Retrieved March 1, 2021, from https://www.bond.org.uk/news/2020/04/how-is-covid19affecting-ngos-finances-and-operations.

35. Holmes, B. J. (2008). Communicating about the emerging infectious disease: The importance of research. Health, Risk \& Society, 10(4), 349-360. Taylor \& Francis.

36. Hope, J., \& Player, S. (2012). Beyond performance management: Why, when, and how to use 40 toolsand best practices for superior business performance. Harvard Business Press.

37. Hsiang, S., Allen, D., Annan-Phan, S., Bell, K., Bolliger, I., Chong, T., Druckenmiller, H., et al. (2020). The effect of large-scale anti-contagion policies on the COVID-19 pandemic. Nature, 584(7820),262- 267. Nature Publishing Group.

38. Jordà, Ò., Singh, S. R., \& Taylor, A. M. (2020). Longer-run economic consequences of pandemics.National

a. Bureau of economic research.

39. Katz, R. A., \& Page, A. (2010). The role of social enterprise. Vt. L. Rev., 35, 59. HeinOnline.

40. Kerlin, J. A. (2006). Social enterprise in the United States and Europe: Understanding and learning fromthe differences. Voluntas: International Journal of Voluntary and Nonprofit Organisations, 17(3),

a. 246. Springer.

41. Kerlin, J. A. (2009). Social enterprise: A global comparison. UPNE.

42. Ketokivi, M., \& Mantere, S. (2010). Two strategies for inductive reasoning in organisational research.Academy of management review, 35(2), 315-333. Academy of Management Briarcliff Manor,NY.

43. Kowalski, L. P., Sanabria, A., Ridge, J. A., Ng, W. T., de Bree, R., Rinaldo, A., Takes, R. P., et al. (2020).COVID-19 pandemic: Effects and evidence-based recommendations for otolaryngology and 
headand neck surgery practice. Head \& neck, 42(6), 1259-1267. Wiley Online Library.

44. Kumar, D., Malviya, R., \& Sharma, P. K. (2020). Coronavirus: A review of COVID-19. EJMO, 4(1), 8-25.

45. Lambooy, T., Anthoni, P., \& Argyrou, A. (2020). Aren't we all pursuing societal goals in ourbusinesses? Defining "societal purpose" as pursued by social enterprises. Sustainable Development, 28(3), 485-494. Wiley Online Library.

46. Leach, M., MacGregor, H., Scoones, I., \& Wilkinson, A. (2021). Post-pandemic transformations: Howand why COVID-19 requires us to rethink development. World Development, 138, 105233.

a. Elsevier.

47. Lenzen, M., Li, M., Malik, A., Pomponi, F., Sun, Y.-Y., Wiedmann, T., Faturay, F., et al. (2020). Global socio-economic losses and environmental gains from the Coronavirus pandemic. PLoS One, 15(7), e0235654. Public Library of Science, San Francisco, CA, USA.

48. London, M., \& Morfopoulos, R. G. (2009). Social entrepreneurship: How to start successful corporatesocial responsibility and community-based initiatives for advocacy and change.

Routledge.

49. London, T., \& Hart, S. L. (2010). Next-Generation Business Strategies for the Base of the Pyramid: NewApproaches for Building Mutual Value (paperback). FT Press.

50. Lyon, F., \& Owen, R. (2019). Financing social enterprises and the demand for social investment. 51. Strategic

a. Change, 28(1), 47-57. Wiley Online Library.

52. Lyon, F., \& Sepulveda, L. (2009). Mapping social enterprises: Past approaches, challenges and future directions. Social Enterprise Journal. Emerald Group Publishing Limited.

53. Mark Stephens. (, 2020). Coronavirus and the impact on output in the UK economy-Office for National Statistics. Retrieved March 1, 2021, from https://www.ons.gov.uk/economy/grossdomesticproductgdp/articles/coronavirusandtheimpact onoutputintheukeconomy/august 2020 
54. Melanie Rapidata. (, 2020). Direct debit cancellations jump under Covid-19 | UK Fundraising. Retrieved March 1, 2021, from https://fundraising.co.uk/2020/04/08/direct-debit-cancellationsjumpunder-covid-19/

55. Nicholls, A. (2013). The social entrepreneurship-Social policy nexus in developing countries. Socialpolicy in a developing world. Edward Elgar Publishing.

56. Obrenovic, B., Du, J., Godinic, D., Tsoy, D., Khan, M. A. S., \& Jakhongirov, I. (2020). Sustainingenterprise operations and productivity during the COVID-19 pandemic: "Enterprise Effectiveness and

a. Sustainability Model.” Sustainability, 12(15), 5981. Multidisciplinary Digital PublishingInstitute.

57. Pan, S. L., \& Zhang, S. (2020). From fighting COVID-19 pandemic to tackling sustainable developmentgoals: An opportunity for responsible information systems research. International Journal of Information Management, 55, 102196. Elsevier.

58. Petrakis, P. E. (2020). Growth and Development Implications of Covid-19. Theoretical Approaches toEconomic Growth and Development (pp. 457-483). Springer.

59. Reeves, A., McKee, M., \& Stuckler, D. (2014). Economic suicides in the great recession in Europe and

a. North America. The British Journal of Psychiatry, 205(3), 246-247. Cambridge UniversityPress.

60. Saunders, M., Lewis, P., \& Thornhill, A. (2007). Research methods. Business Students 4th editionPearson

a. Education Limited, England.

61. Saunders, M. N., Lewis, P., Thornhill, A., \& Bristow, A. (2015). Understanding research philosophyand approaches to theory development. Pearson Education.

62. Schjoedt, L., Brännback, M. E., \& Carsrud, A. L. (2020). Social Media in an Entrepreneurship Context.

a. Understanding Social Media and Entrepreneurship (pp. 3-13). Springer. 
63. Skilled Impact. (2018, January 31). Social Enterprises and Sustainable Development Goals I Blog. 64. Skilled

a. Impact. Retrieved March 1, 2021, from https://skilledimpact.com/social-enterprises-sdg/ Social Enterprise UK, C. P. (2020, February 24). Coronavirus Support and Resources ». Coronavirus

b. Support and Resources, » Social Enterprise UK. Retrieved March 1, 2021, from

c. https://www.socialenterprise.org.uk/coronavirus-information/

65. Stinchcombe, A. L. (2000). Social structure and organisations. Emerald Group Publishing Limited.

66. Tidd, J., \& Bessant, J. R. (2020). Managing innovation: Integrating technological, market andorganisational change. John Wiley \& Sons.

67. Verma, S., \& Gustafsson, A. (2020). Investigating the emerging COVID-19 research trends in the fieldof business and management: A bibliometric analysis approach. Journal of Business Research, 118

a. 253-261. Elsevier.

68. Yoosefi Lebni, J., Abbas, J., Moradi, F., Salahshoor, M. R., Chaboksavar, F., Irandoost, S. F., Nezhaddadgar, N., et al. (2020). How the COVID-19 pandemic affected economic, social, political, and cultural factors: A lesson from Iran. International Journal of Social Psychiatry, 0020764020939984. SAGE Publications Sage UK: London, England.

69. Young, D. R. (2013). If not for profit, for what? (1983 Print Edition) Lexington Books. 
